\title{
Body Composition Parameters of Students
}

\author{
Kirtiraj, Surabhi Singh* and Aayushi Saini \\ Family Resource Management, Sardarkrushinagar Dantiwada Agricultural University \\ Sardarkrushinagar, Gujarat, India \\ *Corresponding author
}

\section{A B S T R A C T}

\section{Keywords}

LBM, BMI, TBW, Protein

\section{Article Info}

Accepted:

20 February 2020

Available Online:

10 March 2020
This research study was planned to analyze body composition parameters of students in ASPEE College of Home Science \& Nutrition, SDAU. It is crucial to point out here that body composition parameters of majority of the students did not fall within optimum level category. It gives a sign of malnutrition amongst them. This issue needs to deal with urgently by sensitizing students about their health and nutrition level.

\section{Introduction}

Body composition and fat mass assessment involve technical-methodological issues that should be considered because adipose tissue partitioning plays an important role in metabolic and cardiovascular risk assessment. The human body is mainly composed of four muscular-level components: water, fat, proteins and minerals, usually in descending order of amounts. The substance that has attracted the most attention is fat. This is a well-established fact that an excessive amount of body fat is related to increased morbidity and mortality.

Few researchers' articles stated that significant trends were observed for body fat, body fat percentages and BMI with age (Singh et al., 2013). In recent years, studies have showed that the body composition irregularities are closely related to lipid metabolic disorders such as obesity, diabetes and other disease that may be risk factors for cardiovascular disease.

In physical fitness, body composition is used to describe the percentages of fat, bone, water and muscles in human bodies. Because muscular tissue takes up less space in the body than fat tissue, body composition, as well as weight, determines leanness. Nutritional status of students was analyzed in the present study through analyzing various 
body composition parameters. The present study was planned with major objective to find out body composition parameters of students of SDAU, Gujarat.

\section{Materials and Methods}

\section{Research Methodology}

The research study was conducted in randomly selected under graduate and posts graduate students of ASPEE college of Home Science and Nutrition of SDAU, Gujarat. The sample size for the present study was restricted to 52 students and simple random sampling method was used for sample selection.

\section{Results and Discussion}

\section{Personal profile of students}

Table 2 and Figure 1 pointed out that almost forty per cent students were in standard category and surprisingly, almost 27 per cent
Body Fat Analyzer Instrument was calibrated followed by entering age, gender, and height was measured by stadiometer. Various Body composition parameters such as L.B.M. (Lean Body Mass), M.B.F. (Mass Body Fat), S.L.M. (Soft Lean Mass), Mineral, Protein, T.B.W. (Total Body Water), V.F.A (Visceral Fat Area) A.C (Abdominal Circumference),W.H.R (Waist Hip Ratio, P.B.F. (Percent Body Fat), B.M.I. (Body Mass Index) and B.M.R (Basal Metabolic Rate) were measured in the present study. The collected data were analysed using descriptive statistics in terms of frequency and percentage and weighted mean.

Table.1 Distribution of respondents according to their gender

\begin{tabular}{|c|l|l|l|}
\hline \multicolumn{1}{|c|}{ S. No. } & \multicolumn{1}{|c|}{ Gender } & \multicolumn{1}{c|}{ F } & \multicolumn{1}{c|}{ (\%) } \\
\hline 1. & Male & 12 & 23.07 \\
\hline 2. & Female & 40 & 76.92 \\
\hline
\end{tabular}

Distribution of students according to their gender indicates that 23.07 per cent were male and majority (76.92\%) of SDAU students were female.

Table.2 Distribution of students according to their body type

\begin{tabular}{|c|l|c|c|}
\hline S.No. & Body Type & F & \% \\
\hline i. & Low Weight & 8 & 15.38 \\
\hline ii. & Low Fat Low Weight & 14 & 26.92 \\
\hline iii. & Standard & 21 & 40.38 \\
\hline iv. & Obese & 4 & 7.69 \\
\hline v. & Law Fat Muscular & 5 & 9.61 \\
\hline
\end{tabular}


Table.3 Body Composition Parameters of students

\begin{tabular}{|l|l|c|c|c|}
\hline S.No. & Body Composition Parameters & \multicolumn{3}{|c|}{$\begin{array}{c}\text { Students } \\
\text { n=52 }\end{array}$} \\
\cline { 5 - 5 } & & Minimum & Maximum & Mean \\
\hline $\mathbf{1}$ & Weight $(\mathrm{kg})$ & 33.5 & 66 & $\mathbf{5 6 . 5}$ \\
\hline $\mathbf{2}$ & LBM $(\mathrm{kg})$ & 28.4 & 56.2 & $\mathbf{4 7 . 9 5}$ \\
\hline $\mathbf{3}$ & MBF $(\mathrm{kg})$ & 1.4 & 23.2 & $\mathbf{8 . 5 5}$ \\
\hline $\mathbf{4}$ & SLM $(\mathrm{kg})$ & 26.2 & 52.6 & $\mathbf{4 4 . 6 5}$ \\
\hline $\mathbf{5}$ & MINERAL $(\mathrm{kg})$ & 1.9 & 3.8 & $\mathbf{3 . 3}$ \\
\hline $\mathbf{6}$ & PROTEIN $(\mathrm{kg})$ & 5.8 & 12.1 & $\mathbf{1 0 . 1}$ \\
\hline $\mathbf{7}$ & TBW $(\mathrm{kg})$ & 20.4 & 40.5 & $\mathbf{3 4 . 5 5}$ \\
\hline $\mathbf{8}$ & PBF $(\%)$ & 3.4 & 37.2 & $\mathbf{1 5 . 7 5}$ \\
\hline $\mathbf{9}$ & BMI $\left(\mathrm{Kg} / \mathrm{m}^{2}\right)$ & 13.3 & 28.5 & $\mathbf{1 9 . 3}$ \\
\hline $\mathbf{1 0}$ & VFA $\left(\mathrm{Cm}{ }^{2}\right)$ & 20 & 92 & $\mathbf{2 7 . 0}$ \\
\hline $\mathbf{1 1}$ & AC $(\mathrm{Cm})$ & 60.2 & 83.2 & $\mathbf{7 0 . 7 5}$ \\
\hline $\mathbf{1 2}$ & WHR & 0.64 & 0.84 & $\mathbf{0 . 6 8}$ \\
\hline $\mathbf{1 3}$ & BMR $(\mathrm{K} \mathrm{Cal})$ & 1081 & 1593 & $\mathbf{1 4 1 2}$ \\
\hline $\mathbf{1 4}$ & AGE $(\mathrm{yrs})$ & 17 & 25 & $\mathbf{2 2}$ \\
\hline $\mathbf{1 5}$ & Height $(\mathrm{Cm})$ & 145 & 178 & $\mathbf{1 7 1}$ \\
\hline & & & & \\
\hline
\end{tabular}

Mean weight of students were measured as $56.5 \mathrm{~kg}$. Though, there were wide differences between weights of respondents having minimum and maximum weight among the students. Mean lean body mass of students was found $47.95 \mathrm{~kg}$, whereas, minimum and maximum LBM of students was found 28.4 $\mathrm{kg}$ and $56.2 \mathrm{~kg}$ respectively. Mean MBF of students was measured $8.55 \mathrm{~kg}$. Similarly, Mean SLM of students was measured 44.65 $\mathrm{kg}$ respectively. Mean of mineral content amongst students $3.3 \mathrm{~kg}$ respectively were very low content found in students. Mean VFA of students was measured as $27 \mathrm{~cm}^{2}$. The minimum VFA of students was found 20 $\mathrm{cm}^{2}$ which is too low than the normal range, while the maximum VFA of students was found $92 \mathrm{~cm}^{2}$. Mean of Abdominal circumference was found within normal range of students i.e. $70.75 \mathrm{~cm}$. Again minimum waist hip ratio of students was 0.64 and maximum was 0.84 , which is less than the normal range. Mean BMR of students was measured $1412 \mathrm{Kcal}$. 
Table.4 Level of body composition parameters amongst students

\begin{tabular}{|c|c|c|}
\hline Parameters level & Students $(\mathrm{n}=52)$ & \\
\hline LBM & $\mathbf{F}$ & $\%$ \\
\hline Under & 39 & 75.00 \\
\hline Optimum & 11 & 21.15 \\
\hline Total & 52 & 100 \\
\hline \multicolumn{3}{|l|}{ MBF } \\
\hline Under & 29 & 55.76 \\
\hline Optimum & 19 & 36.53 \\
\hline Total & 52 & 100 \\
\hline \multicolumn{3}{|l|}{ SLM } \\
\hline Under & 39 & 75.00 \\
\hline Optimum & 12 & 23.0759 \\
\hline Total & 52 & 100 \\
\hline \multicolumn{3}{|l|}{ Mineral } \\
\hline Under & 38 & 73.07 \\
\hline Optimum & 10 & 19.23 \\
\hline Over & 4 & 7.69 \\
\hline Total & 52 & 100 \\
\hline \multicolumn{3}{|l|}{ Protein } \\
\hline Under & 33 & 63.46 \\
\hline Optimum & 19 & 36.53 \\
\hline Over & 0 & 0.0 \\
\hline Total & 52 & 100 \\
\hline \multicolumn{3}{|l|}{ TBW level } \\
\hline Under & 39 & 75.00 \\
\hline Optimum & 11 & 21.15 \\
\hline Over & 2 & 3.84 \\
\hline Total & 52 & 100 \\
\hline \multicolumn{3}{|l|}{ PBF } \\
\hline Under & 20 & 38.46 \\
\hline Optimum & 28 & 53.84 \\
\hline Over & 4 & 7.69 \\
\hline Total & 52 & 100 \\
\hline
\end{tabular}

Table 4 depicts that maximum students had below the optimum level of LBM, MBF, SLM, mineral, protein and TBW. While more than half of the students had above the optimum level of Percent Body Fat. It can be concluded that maximum students were under nutritive except few. There is a need to pay attention towards it for maintaining optimum level of nutrition amongst students. 
Table.5 Distribution of students according to their BMI

\begin{tabular}{|l|c|c|}
\hline BMI $\left(\mathbf{K g} / \mathbf{m}^{\mathbf{2}}\right)$ & F & \% \\
\hline Under weight $(<\mathbf{1 8 . 5})$ & 23 & 44.23 \\
\hline Low weight (18.5-20) & 11 & 21.15 \\
\hline Normal weight (20-25) & 14 & 26.92 \\
\hline Obese I (25-30) & 4 & 7.692 \\
\hline Total & $\mathbf{5 2}$ & $\mathbf{1 0 0}$ \\
\hline
\end{tabular}

BMI is a good indicator of nutritional status of human. BMI of students were also measured. Findings indicate that 44.23 per cent of the students were under weight, 26.92 per cent were normal weight, 21.15 per cent were low weight and a few students were found obese also (7.69\%).

Table.6 Distribution of students according to their Waist-hip ratio

\begin{tabular}{|c|c|c|c|}
\hline S. No. & WHR & F & \% \\
\hline 1. & $<0.7$ & 12 & 23.07 \\
\hline 2. & $0.7-0.8$ & 33 & 63.46 \\
\hline 3. & $>0.8$ & 2 & 3.84 \\
\hline
\end{tabular}

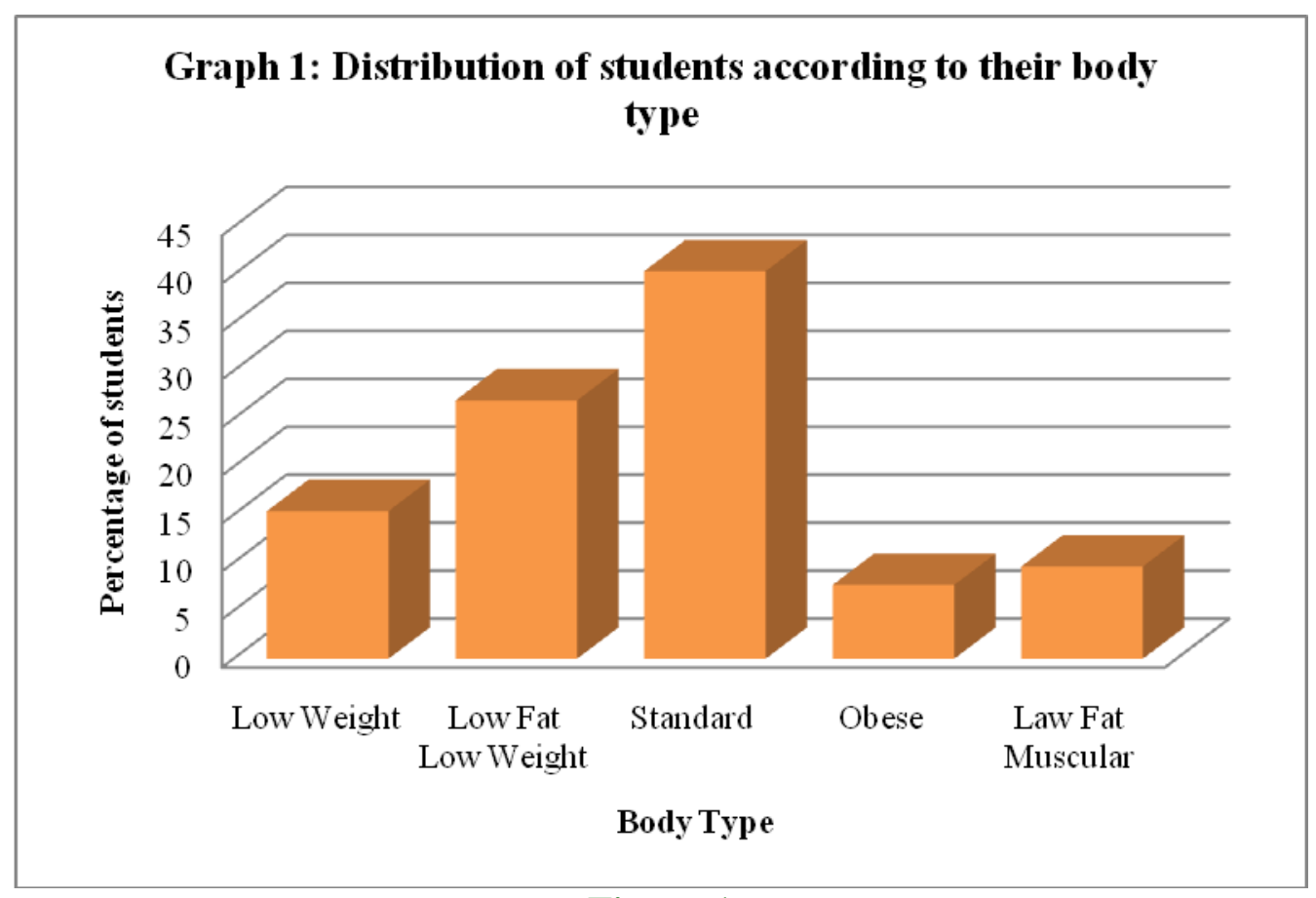

Figure.1 
63.46 per cent students fell into the medium category of WHR, 23.07 Per cent students were normal and 3.84 per cent students were under in the risk. It can be inferred from the results that more than half of the students are malnutritive and they require paying a heed towards their dietary habits and activity pattern to be healthy and fit.

Majority of the students did not have optimum level of various body composition parameters. This may be due to lack of proper food habits or ignorance about nutrition. Hence, this is high time to sensitize students about their nutritional level.

Intervention programmes should be developed to create awareness amongst students. Further studies can be carried out to study awareness level and knowledge of the students regarding nutrition. Health camps and awareness programme should be organized for students nearby about their health condition and for treatment.

\section{References}

Baumgartner R. N. Body composition in healthy aging. Ann N Y Acad Sci 2000

Heyward V.H., Wagner D.R. 2004. Applied body composition assessment, $2^{\text {nd }}$ ed. Champaign, IL: Human Kinetics; 2004.

Naser K.A., Gruber A., Thomson G.A. The emerging pandemic of obesity and diabetes: are we doing enough to prevent a disaster? Int $\mathbf{J}$ Clin Pract. 2006;60 (9):1093-1097.

Singh S., Ahlawat S., Pandya S., Prafull B. 2013. Anthropometric Measurements and Body Composition Parameters of Farm Women in North Gujarat. Journal of Ergonomics. 3:114. P 1000114.

\section{How to cite this article:}

Kirtiraj, Surabhi Singh and Aayushi Saini. 2020. Body Composition Parameters of Students. Int.J.Curr.Microbiol.App.Sci. 9(03): 2623-2628. doi: https://doi.org/10.20546/ijcmas.2020.903.300 